\title{
もんじゅ開発の原点の再確認
}

1. はじめに

高速炉開発会議がもんじゅについては廃炉を含め抜本 的見直しを行い，高速炻開発の方針と併せて決定すると されている。ふと, 山本七平著の「日本人と原子力」での 「完成品輸入の歴史しかもたない我々には, 実際に始動 してみてはじめて発見されるものが多いことを当然のこ ととして認識していない」が頭をよぎった。また CANDU 論争も想い起こされた。

本稿では，もんじゅは商用炉とどういう差別化を図り つつ進めたかに焦点をあててみる。

\section{2. 画期的な国策}

高速炉開発会議の冒頭, 議長の経産大臣は高速炉開発 について「全ての関係者が自覚し, 連携強化することが 重要。責任を果たす気概を持ってほしい」と強調したと 報じられた。最近はこれと逆行していることを物語って いる印象だ。

我が国に扔ける高速炉の開発は, 原子力長計 (1956 年) に始まる。そこでは増殖型動力炉の国産化を目標にお き, 高速炉開発を国策として進めるために, 動燃事業団 が 1967 年発足した。電力, メーカからは幹部が参画し, 電力を中心に米国フェルミ炉での実験計画に参加してい た技術者が中心的役割を果たした。また，電力からは運 転経験を積むため運転員の半分が参集した。資金につい ても，建設費 5,900 億円のうち，1,400 億円を民間が支出 した。

国はもんじゅが新型の原型炉であることを踏まえ，軽 水炉とは異なる姿勢で臨んだ。安全性については国が福 井県に対し, 安全審査の結果を責任をもって説明した上 で, 中川知事から建設同意を得た。当時の国の覚悟が伝 わってくる。一方, 原子力安全委員会は高速炉開発を育 てていく方針の下，技術の本質から検討し，基本的な考 え方を示した。

\section{3. プルトニウムリサイクル}

我が国は当初からプルトニウム利用を基本方針として きたが，プルサーマルが開始されるまでのプルトニウム 利用は再処理, MOX 加工と連携して 25 年間運転したふ げんが，これを支え続けてきた。INFCE（国際核燃料サ

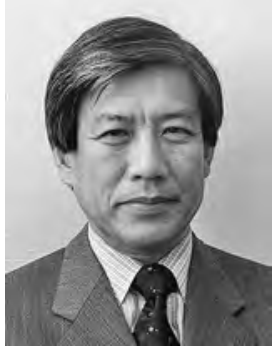

柳澤 務（やなぎさわ・つとむ）

日本原子力研究開発機構フェロー 東大大学院原子力工学専門課程修了。 動燃に入社後, もんじゅ建設所所長代理, ふげん所長，大洗工学センター所長，理事 などを歴任。
イクル評価) (1977-80 年)では「ふげんは日本の原子力政 策を写す鏡」と評価された。この実績があればこそ核兵 器をもたない国で唯一プルトニウム利用が世界から認め られている。我が国の安全保障にもつながっていく。米 国原子力学会からふげんの閉鎖にあたり我が国のプルト ニウムリサイクル技術の確立ということで我が国初のラ ンドマーク賞を授与された。いわばプルサーマルの先鞭 をつけた訳だ。次にもんじゅがこの受賞を引き継いで実 体のある高速炉サイクルの先駆けとして継続的に挑戦し ていく役割を負っている。

\section{4.ループ型原型炉・設計力育成}

もんじゅは現存する唯一のループ型原型炉であり，同 時期に設計された 30 万 $\mathrm{kWe}$ 級の米国の CRBR，独の SNR-300 と競いあっていたが，これらは運転開始に到 らず中止となった。将来のタンク型とループ型の比較評 価に耐えられる成果を出すことが国際的にも極めて重要 な意義がある。ASTRID を計画していた仏 CEA 幹部がも んじゅ訪問の際, プラント寿命の折り返し点での安全性, 信頼性を考えるとループ型の魅力への評価も示された。

もんじゅのトラブルを含めての技術開発の成果は別に 讓るが運転を重ねながらの本格的技術開発は今後に残さ れており, 大胆には実験炉常陽での成果のレベルに留 まっているとはいいすぎだろうか。基礎技術に裏打ちさ れた設計力がなければ海外からの技術も倰駕できない。

\section{5. 地域の目}

もんじゅは地元の事前調查陳情を受け敦賀の白木地区 を候補地に選定したのは 1970 年であった。1995 年の 2 次系ナトリウム漏えい事故直前に ATR 実証炉中止決定 を受け，ふげんの運転停止が地元に何の相談もなく決定 され，地元からは裏切られたという印象だった。ナトリ ウム漏れ事故後の対応も不適切で地元からは原子力に関 して国, 動燃への信頼は大きく失隊した。福井県はじめ 3 県知事がプルトニウム利用政策や原子力開発に扔ける 国と地方の位置付け等の合意形成に関して要望があり, それを受けた原子力長計がまとまるのに 5 年かかった。 また，もんじゅ設置許可の安全審査に関する訴訟では金 沢高裁で国が敗訴し，最高裁の判決まで 2 年半が経過し 
た。この間，地域では廃炉の声さえあり，もんじゅの推 進は共感されなかった。その後に改造工事の許認可, 改 造工事, 確認試験等で 7 年程かかり, 事故後 14 年半ぶり に運転再開したが，燃料交換の後始末で炉内中継装置の 落下, 更に 1 万件の機器点検漏れなどの保守管理不備の 問題が起こり 6 年経て今日に到っている。

以上のように開発段階の原型炉であることを十分認識 した上での丁寧な備え, 構えが不十分であり, 国を挙げ て総力であたるべきという基本姿勢がゆらいでいたとい える。

原子力の研究開発, 事業を進めるには立地地域の理 解, 合意, 約束履行なくしては現実に一歩も具体化でき ない。理解, 合意形成ではなく, 地元との共働活動, 参 画にしていかねばならない。もんじゅ事故を踏まえての 信頼回復活動の中から, 新型炉のもんじゅを中核に据え た産官学連携の福井県エネルギー研究開発拠点化計画が 立ち上がった。この中には敦賀に福井大学附属国際原子 力工学研究所の設置もあり, 計画は拡充発展し, 地域の 活性化の重要な索引力として期待されている。

このようにもんじゅには運転しながらの技術開発が期 待されており，このまま運転されないと地域との約束履 行にもとる上に, 成果も生みださないとなれば炉内の燃 料の取扱いも十分慎重にしていかなくてはならない。

地元の方々はもんじゅが運転され，世界に誇れる成果 を出してくれることをずっと見守ってきた。現場の職員 はずっと心を痛めてきた。最後まで心を砕かないといけ ないだろう。

\section{6. 国際競争と協力}

国際的に第 4 世代システムが検討されているように軽 水炉の実用化はその第 1 歩である。高速炉開発は欧米で は仏の原型炉 Phenix の運転停止で, 日本の常陽，もん じゅのみ動いている。積極的なのはロシア, インド, 中 国で韓国や米国も研究を続けている。日本は高速炉開発 の先進国であり注目もされている。もんじゅが成果を出 さずに停止すれば競争相手の脱落と受け止められても仕 方ない。

このような状況をみると高速炉に関する国際情勢は現 物のあるもんじゅの強みを活用して, 仏, 米は無論, 口 シア，インド，中国ともまずは現物の高速炬プラント経 験の技術交流・研究協力に向かうべきでないか。 WANO (世界原子力発電事業者協会) の中に高速炉グ ループを設置し, 現場同士で経験を共有し, 情報・技術 交流する活動も進められている。更にMA 入り燃料の 燃焼に関する産業レベルでの実用化見通しの GACID 計 画が日仏米の間で準備されている。

ASTRID との協力は様々に論ぜられているが, 自らの プラント設計力の充実やループ型の技術評価による自主 技術育成なくしては，我が国のためにならない。このよ うに政策に係わるものは関係者が揃っての研究現場, 現
物も含めての公式の調查団派遣が必要ではないか。

もんじゅは試験, 運転を積みながら研究開発し, 次世 代を担う技術や人材を育てる実践拠点として国際開発道 場の役割を担っている。2010 年運転再開では欧米から 技術者が滞在し熱い技術交流が行われた。また高速炉の 万が一の事故時に備えて, 専門家集結や過酷事故時の対 応を検討するセンター構想も考えられる。

\section{7. 今後の方向}

もんじゅについては，廃炉も含め抜本的見直しを行う となれば「もんじゅ研究計画」のスリム化を考えざるをえ ない。原子力学会が9月末に示したもんじゅに関する見 解に記載されているように, 慎重に出力を上昇させ, 成 果を精査の上, 時間をかけずに取得し, 長期にわたり運 転するのでなく限定された運転サイクルにとどめ, 適切 なコストに抑制する工夫をと訴えている。切り詰めた運 転を考え，早く廃炉の段階に移行する計画が望まれる。 いずれにしても開発段階での規制のあり方の検討が必要 となる。

次にどのような成果が必須かについて私見を述べてみ たい。今後の高速炉開発戦略にとって鍵として以下の 4 つの課題をとりあげる。

1. 第 4 世代原子力システムで重要な MA 入りあるいは 高次プルトニウム燃料の炉心特性試験

2. 福島事故を踏まえて全電源喪失時自然循環除熱試験

3. 炉心とタービン系を組み合わせた発電システムの過渡 応答試験

4. 出力運転での性能評価からの設計力の育成

これらの課題に向けての試験実施にあたっては, 課題 に応じた運転モードを切り詰めた形で設定する。定格出 力がむずかしければ, 高出力あるいは 2 次系空気冷却器 の崩壊熱除熱モードでの試験とシミュレーションを組み 合せた丁寧な分析評価を行うことになる。反応度が厳し ければ手続きが煩雑になりむずかしいであろうが濃縮ウ ランで補うことも可能である。試験計画の立案にあたっ ては専門家による出力試験技術検討会のような場を早急 に設けて検討を進めることが望まれる。

これらの成果を挙げることによりもんじゅ計画が「画 竜点睛を欠く」,「九仞の功を一筫に欠く」といわれるの に対し, 美しい竜や山ではないかもしれないが, 睛(ひと み)を点(い)れ，一筫(もっこ)を積むことでまともな姿 に仕上げないといけない。

ロシアの BN-800 が発電開始したが, 建設着手から 28 年かかっている。このように開発は長丁場であり, 一筋 縄ではいかない。再出発に向けて, 容易に崩されない国 を挙げてのもんじゅの要塞化が必要であろう。またこの 機会に行政も技術開発戦略の議論も幅広くできるよう新 たな一元化の方向をめざすべきと考える。

(2016 年 10 月 9 日 記) 